\title{
Workplace wellbeing programs: If you build it they may NOT come...because it's not what they really need!
}

\author{
Gordon B. Spence
}

\begin{abstract}
Public and private sector interest in employee wellbeing has grown steadily in the past 20 years. Arguably the most visible manifestation of this interest is workplace health promotion and wellbeing (WorkWell) programs, which can be found in various guises within many contemporary organisations. Despite their recent proliferation, research in this area has focused mainly on how participation in these programs impacts upon a narrow range of factors related to finance (e.g. health care costs) and productivity (e.g. absenteeism). Whilst the focus of these programs is invariably positive (insofar as they aim to improve physical, psychological and social functioning), it cannot be assumed that employees will be positively disposed towards them. Indeed, empirical and anecdotal evidence suggests that employee participation is a widespread challenge when implementing WorkWell initiatives. This paper introduces the concept of employee receptivity and reviews an array of factors that may influence participation. After reviewing pilot data from an employee wellbeing research project, three primary conclusions are presented. First, that participation may be low because such programs may not provide employees with what they most need. Second, that employee receptivity may be an important factor in making decisions about the implementation of WorkWell programs. Finally, there may be times when organisations would be far better served by concentrating on basic human relations issues than making sizable investments in formal, structured employee wellbeing programs.
\end{abstract}

Keywords: Employee wellbeing, employee receptivity, organizational trust, change readiness, basic need satisfaction

\section{Introduction}

Workplace health and wellbeing continues to be an issue of global significance. Over a decade ago, Wainwright and Calnan (2002) argued strongly that work stress had reached epidemic proportions within western industrialised societies. Recent evidence suggests that little has changed and contemporary workplaces continue to be studied in the search for answers about what causes and what prevents work stress (e.g. Nixon, Mazzola, Bauer, Kruger, \& Spector, 2011). According to the World Health Organisation (WHO), the workplace represents a key channel for health promotion, a view that appears to be widely held (Goetzel \& Ozminkowski, 2008). For example, as Joslin, Lowe and Peterson (2006) state:

"Chronic diseases are often preventable; therefore, health promotion efforts taking place in a setting where individuals are consistently present (such as the worksite) may have 
public health benefits in numerous countries, with varying health care systems in place"

(p. 316).

Recognising that the economic and material basis of any society is dependent on the productive capacity of its workforce, the WHO has repeatedly called for the development of national strategies to secure the physical, psychological and social health and wellbeing of workers worldwide (WHO, 2007). In Australia this call appears to have been answered, with the 2008 National Partnership Agreement on Preventive Heath and, more recently, the 2011 Australian Work Health and Safety Act stimulating the creation of health initiatives in all states and territories (e.g. the NSW Healthy Workers Initiative). According to the federal Department of Health, these initiatives are designed to encourage and support workplaces to offer a range of health promotion initiatives to improve the lifestyles of working adults (Commonwealth of Australia, 2015).

Whilst government support for the creation of healthier workplaces is undoubtedly a good thing for workers, it is interesting to note that participation rates in employer-sponsored health and wellbeing programs have historically been quite low both in Australia (Crowther, Thwaites, \& Zhou, 2004) and abroad (Linman et al, 2008). Given this, the purpose of this article is to: (i) explore reasons employees might decide against participating in such programs, (ii) introduce the concept of employee receptivity as a focus for future research, and (iii) outline an agenda for such research.

\subsection{What is a "WorkWell" program?}

According to the 2014 Working Well: Global Survey of Health Promotion, Workplace Wellness and Productivity Strategies (Buck, 2014), public and private sector interest in employee health and wellbeing has grown steadily over the past decade. Arguably the most visible manifestations of this interest are the workplace health promotion programs that can be found in various guises within many Australian organisations.

Before these programs are examined in greater detail, it should be noted that health and wellbeing are conceptualised in this article along the lines of the WHO's seminal definition as "a state of complete physical, mental and social well-being and not merely the absence of disease or infirmity" (WHO, 1948). Based on this definition, a broad range of employer-sponsored service or product offerings can be considered relevant due to the contribution they might make to a "complete" state of health. These contributions might occur across any or all of the dimensions listed in Table 1 below.

For ease of reading, the term "WorkWell" will henceforth be used to refer to any configuration (program) of health and wellbeing products or services that: (i) concerns itself with both health promotion and illness prevention activities, and (ii) possesses some formality and structure, which might include:

- An explicitly articulated sequence of activities, including some instruction on how an employee participates and what participation involves.

- A requirement that employees formally register to participate in some way.

- Internal promotions that articulate the benefits for employees and encourage participation.

- A cost centre or budget to support the program components.

- Some form of organizational evaluation (e.g. workshop satisfaction ratings) to assess impact. 
Table 1. Dimension of workplace wellbeing represented in WorkWell programs

\begin{tabular}{|c|c|c|}
\hline Wellbeing dimension & Description & Example of type of service \\
\hline $\begin{array}{l}\text { Physical ill health - } \\
\text { prevention }\end{array}$ & $\begin{array}{l}\text { Any offering that seeks to } \\
\text { safeguard an employee's } \\
\text { physical health or lower health } \\
\text { risk factors }\end{array}$ & $\begin{array}{l}\text { Flu vaccinations, ergonomic } \\
\text { assessments, BP tests }\end{array}$ \\
\hline $\begin{array}{l}\text { Physical health - } \\
\text { promotion }\end{array}$ & $\begin{array}{l}\text { Any offering that encourages or } \\
\text { supports an improved physical } \\
\text { health status }\end{array}$ & $\begin{array}{l}\text { Gym membership, Global } \\
\text { Corporate Challenge, fruit } \\
\text { deliveries }\end{array}$ \\
\hline $\begin{array}{l}\text { Mental ill health - } \\
\text { prevention }\end{array}$ & $\begin{array}{l}\text { Any offering that helps } \\
\text { employees to manage the } \\
\text { adverse effects of work stress or } \\
\text { recover from a work-related } \\
\text { trauma or personal crisis }\end{array}$ & $\begin{array}{l}\text { EAP offerings such as } \\
\text { workplace counseling, } \\
\text { outplacement services, critical } \\
\text { incident debriefing }\end{array}$ \\
\hline $\begin{array}{l}\text { Mental health - } \\
\text { promotion }\end{array}$ & $\begin{array}{l}\text { Any offering that supports } \\
\text { flourishing psychological health } \\
\text { in employees }\end{array}$ & $\begin{array}{l}\text { Workplace coaching, Positive } \\
\text { Psychology seminars, } \\
\text { meditation, yoga classes }\end{array}$ \\
\hline Financial wellbeing & $\begin{array}{l}\text { Any offering (beyond ordinary } \\
\text { remuneration practices) that } \\
\text { supports employees to improve } \\
\text { their personal financial status }\end{array}$ & $\begin{array}{l}\text { Financial advice, salary } \\
\text { packaging, retirement } \\
\text { planning }\end{array}$ \\
\hline Career wellbeing & $\begin{array}{l}\text { Any offering (beyond ordinary } \\
\text { career management activities) } \\
\text { that seeks to optimize the } \\
\text { professional growth and } \\
\text { development of employees }\end{array}$ & $\begin{array}{l}\text { Mentoring, flexible work } \\
\text { practices }\end{array}$ \\
\hline Social wellbeing & $\begin{array}{l}\text { Any offering that encourages } \\
\text { social connections within } \\
\text { organisations }\end{array}$ & $\begin{array}{l}\text { Social Club support, } \\
\text { volunteering schemes, } \\
\text { lunchtime sport }\end{array}$ \\
\hline $\begin{array}{l}\text { Environmental } \\
\text { wellbeing }\end{array}$ & $\begin{array}{l}\text { Any offering that seeks to build } \\
\text { employee connections to the } \\
\text { natural world or design office } \\
\text { spaces that support optimal } \\
\text { functioning }\end{array}$ & $\begin{array}{l}\text { Creation of green spaces in } \\
\text { office environments, } \\
\text { workplace design }\end{array}$ \\
\hline
\end{tabular}

\subsection{Challenges associated with "WorkWell" programs}

Whilst the presence of these programs in organisations is positive (insofar as they aim to improve physical, psychological and social functioning), recent evidence suggests that 
Australian organisations may still be unsure about the value and positioning of such programs. For example, an ongoing difficulty seems to be the linking of employee health outcomes to business performance, which has typically relegated WorkWell services to the level of discretionary expenditure (PWC, 2010). This appears to be an ongoing global challenge, with $26 \%$ of organisations reporting the absence of a business case to support a wellness strategy, and $20 \%$ believing that managing employee health is not the role of an organisation (Buck, 2014). In addition, the task of developing comprehensive, coherent programs appears to have been a challenge for many employers and has resulted in an amorphous collection of healthrelated services, delivered by multiple vendors in a relatively uncoordinated way (PWC, 2010). Furthermore, evidence exists that these programs are not rigorously evaluated. For example, survey data collected from 319 Australian HR professionals indicated that almost half the organisations they represented (46\%) make no attempt to measure the impact of WorkWell initiatives and those that do usually limit their focus to simple usage and satisfaction measures (McCarthy, Almeida, \& Ahrens, 2011). Similar findings have previously been reported on programs offered in the United States (Goetzel \& Ozminkowski, 2008) and the United Kingdom (McGillivray, 2002).

Despite the personal assistance offered by such programs, employee participation rates are typically quite low (Goetzel \& Ozminkowski, 2008; L. Linman et al., 2008; McCarthy et al., 2011; McGillivray, 2002; Rongen et al., 2014) and several studies have sought to examine the common barriers to participation (Bright et al., 2012; Lakerveld et al., 2008; Linnan, Sorensen, Colditz, Klar, \& Emmons, 2001; Person, Colby, Bulova, \& Eubanks, 2010; Robroek, van Lenthe, van Empelen, \& Burdorf, 2009). Indeed, the participation issue has become so significant in the United States that the use of incentives is now commonplace, with estimates suggesting that incentive increases of $\$ 100$ can improve participation rates by 10\% (Goetzel \& Ozminkowski, 2008). As a result, incentives are considered to be a key to successful program implementation (Rula \& Sacks, 2009) and lack of formal incentives has been confirmed to be a major barrier to participation (Person et al., 2010). Not surprisingly, the 2014 Working Well survey reported that $90 \%$ of US companies are currently using some form of incentive (Buck, 2014). In contrast, only $29 \%$ of Australian companies reported incentive use. This strategy would seem to be less important in Australia however, as the health care costs of employees are met primarily by the state, not by employers (unlike the U.S.). This is confirmed by recent data that showed Australian employers ranked "reducing health care costs" as the least important of 10 common program objectives, with "improving workforce morale/engagement" considered to be most important (Buck, 2014).

\subsection{On building WorkWell programs for employees}

There are several reasons (other than reducing health care costs) Australian employers ought to place a high level of importance on employee wellbeing. In the first instance, the Australian Work Health and Safety Act 2011 requires businesses to act in ways that safeguard the physical and psychological health of workers. Beyond compliance with federal and state legislation, Crowther et al. (2004) suggests that focused attempts to enhance employee wellbeing are worthwhile because they can improve productivity (either by increasing engagement and/or reducing absenteeism/presenteeism), morale and teamwork, staff retention, employer brand and company image (which helps to attract talented potential employees). These programs also provide organisations with a way of demonstrating their ethical standing as caring employers and seem to have become a popular strategy for exercising corporate social responsibility (Holmqvist, 2009). 
WorkWell programs appear to be a very benign, positive form of organisational intervention. As indicated in Table 1 above, they generally provide employees with access to low or no cost products, services and/or events (e.g. flu vaccinations, health insurance subsidies, physical fitness challenges) that are designed to improve not just one's experience at work but one's life more broadly. According to several reviews of this literature (Baxter, Sanderson, Venn, Blizzard, \& Palmer, 2014; Goetzel \& Ozminkowski, 2008; Pelletier, 2011; Rongen, Robroek, van Lenthe, \& Burdorf, 2013), such programs have been generally successful at securing such improvements, either by lowering occupational health risks, improving productivity and/or reducing health care costs. Lower absenteeism rates and greater job satisfaction have also been reported, albeit with only small to moderate effect sizes (e.g. Parks \& Steelman, 2008).

In regard to financial returns, ROI research studies have estimated that cost savings of around $\$ 3$ to $\$ 4$ are not uncommon for each dollar expended on WorkWell programs (Goetzel \& Ozminkowski, 2008) with some studies reporting much higher returns, including one that reported a benefit-cost ratio of up to 26:1 (Miller, Zaloshnja \& Spicer, 2007). In a recent metaanalysis of this literature, Baxter, Sanderson, Venn, Blizzard and Palmer (2014) reported somewhat less impressive returns, although an overall weighted ROI of $\$ 2.38$ for every dollar invested was still found.

Whilst research has generally affirmed the value of employee-focused programs, some caution is required when interpreting results from this literature. Not only do effect sizes tend to be small to moderate at best, they are also at their lowest in studies that employ rigorous, high quality research methods (Baxter et al., 2014; Rongen et al., 2013). Nonetheless, given the positive findings that are regularly reported from WorkWell programs, finding ways to maximize employee participation in such programs would seem to be worthwhile.

\section{If you build it, will they come? Factors in employee participation}

Surprisingly, the perspectives and experience of employees are not well represented in the literature and relatively few researchers have investigated why participation rates in WorkWell programs are so low. Where employee-focused research has been reported, it has tended to be concerned with changes in the medical or psychological criteria of interest to employers, such as identifying the demographic profile of participants (Joslin et al., 2006), assessing the beneficial effects of participation across physical/cognitive, social and emotional dimensions (Nohammer, Stummer, \& Schusterschitz, 2011), assessing employee perspectives on changes to workplace culture (Mainsbridge, Cooley, Pedersen, Fraser, \& Cosgrove, 2011), and, more superficially, simple comparisons of participants and non-participants using a variety of health indicators, demographic and lifestyle factors (e.g. Breslow, Fielding, Herrman, \& Wilbur, 1990).

In recent years some attention has been directed towards understanding participation from the employee's perspective, with studies conducted on employee attitudes (Bright et al., 2012), barriers to participation (Person et al., 2010), and motives related to participation (Lakerveld et al., 2008; Robroek et al., 2009). Given the widespread use of WorkWell programs and their generally positive effects, it is useful to consider why employee participation is not higher than it is. A number of possibilities exist.

\subsection{Individual factors impacting participation}

Several individual-level factors can be proposed to explain low employee participation. These include service-needs misalignment, time and work pressures, access to resources, individual 
change readiness, personal locus of responsibility and/or perceptions about the balance of responsibility for change.

Service-needs misalignment. Low participation rates in some organisations may simply be related to the provision of services that have little relevance or interest to employee needs (e.g. tertiary education subsidies for factory floor workers). Whilst this has been noted as a barrier to participation in some studies (e.g. Person et al., 2010), Rongen et al. (2014) argue that this only lowers the likelihood of participation, rather than heavily influencing participation decisions per se.

Time and work pressures. Participation rates are also known to be impacted by employee perceptions of workload and time limitations (Lakerveld et al., 2008; Person et al., 2010). As it will soon be argued, organisations have an important role to play in ensuring that cultural norms do not work against what is being recommended by some program offerings (e.g. company cultures that do not support people taking lunch breaks).

Access to resources. This relates to the broader context of an employee's life and the degree to which employees are able to access resources that support their health and wellbeing (e.g. restorative environments like public parks or community gardens, or social structures like clubs or hobby groups). In line with Hobfoll's (2001) conservation of resources theory, for employees who have fewer social or psychological resources, the availability of programs may be attractive because they provide opportunities (like volunteering or social activities) that they would have difficulty creating themselves.

Change readiness. The next factor is subtler and relates to the degree to which employees are psychologically ready to engage in the personal change that WorkWell programs usually encourage. As the Transtheoretical Model of Change (Prochaska, Prochaska, \& Levesque, 2001) highlights, the change readiness of individuals should never be assumed and if employees are not given opportunities to resolve ambivalence they might hold towards certain changes (e.g. smoking cessation) then they are likely to remain in contemplation and invest little effort in behaviour change.

Locus of responsibility. An additional possibility is that employees may not want help with the aspects of personal health and wellbeing that they see as their own legitimate responsibility. If so, employees' personal beliefs about health change will disincline them to utilize employee-sponsored services and most likely lead them to make their own arrangements outside the workplace.

Balance of responsibility for change. In an early critique of the workplace health promotion movement, Sloan (1987) noted that most interventions were focused on modifying behaviour at the level of the individual, rather than at the level of the organisation. He noted:

"A paradigm of workplace health promotion programs appears to exist: it calls for activities, both large- and small-scale, which are designed to induce health-related behavior change in individuals rather than examining and changing the system of work in which these behaviors may be embedded" (p. 186) 
Whilst it is debatable whether organisations have become better at changing and developing healthier work environments in the 25 years since Sloan's review, his critique highlights a potentially important point. That is, if employees perceive that the change they are being asked to embrace as individuals (through participation in a WorkWell program) is greater than the organisation's preparedness to do likewise, then this may be resented and lead to a resistance and lower employee receptivity to any employer-sponsored offering.

\subsection{Organisational factors impacting participation.}

Organisational-level factors that might help to explain participation rates include the changing nature of the HR function, perceptions of corporate social control, organisational trust and/or the satisfaction of basic needs.

The changing nature of the human resources function. This refers to the observation that contemporary HR managers have moved away from their traditional focus on employee welfare and professional development, and are now primarily concerned with strategic goals and employee performance (Brown, Metz, Cregan, \& Kulik, 2009; Peretz \& McGraw, 2011). According to Brown et al. (2009), this shift away from employee welfare has been challenging for many HR professionals, partially because it has eroded confidence amongst employees that they can (and will) continue to adequately represent their interests. As a result, the promotion of WorkWell services by HR personnel may now be perceived as the execution of a strategic agenda rather than a genuine effort to safeguard the health and wellbeing of employees.

Corporate social control. Another factor that might impact employee participation relates to the idea that workplace health promotion is a veiled form of corporate social control (Holmqvist, 2009). According to Haunschild's (2003) Foucauldian analysis of employee health programs:

"After optimizing the direct use of bodies (Taylorism), optimizing work environments (Human Relations Movement), and lowering risks and consequences of body failure (work safety), organizations today seem to have re-(?)discovered [sic] the whole body as a matter of surveillance and control. This included - among other things - medical screenings (check-ups), fitness programmes, stress management, dietary advices and lifestyle counseling" (p. 6)

This analysis acknowledges the possibility that WorkWell programs are, for all their good intentions, essentially an attempt to shape a workforce, such that it becomes more productive, less costly, more harmonious and ultimately more profitable. However, as Goss (1997) explains, this is not a rejection of the positive contribution that these programs can make, rather it merely suggests that their benefits may come at a cost. Part of that cost is employee resistance, which Haunschild (2003) argues is an inevitable part of all power relations and merely something to be managed.

Organisational trust. A more general trust factor would also appear to play a role in employee attitudes and participation decisions. According to Dietz and Den Hartog (2006) trust accrues based on the degree to which an employee believes their employer has benevolent motives, the ability to meet their obligations, demonstrates acceptable levels of integrity (e.g. fair treatment), and behaves in a fashion that is predictable and reliable. These dimensions are relevant because 
any interest or inclination that an employee has towards WorkWell programs will be influenced by, for example, employee perceptions of motive (benevolence). An example of this would be the perception that the program is nothing more than a public relations exercise, designed to project a positive image to the outside world. From this perspective, programs might be seen simply as a tool to enhance employer brand, or the perception that the company is a good place to work (Backhaus \& Tikoo, 2004). In addition, receptivity to programs would also be influenced by how the organisation might use personal data, such as health data (integrity), the degree to which employees 'hear' consistent messages (predictability), such as the regular promotion of services and benefits, and the belief the organisation has the requisite skills and knowledge to successfully manage such programs (ability).

Basic psychological need satisfaction. This factor relates to employees' experience of having their basic psychological needs supported and satisfied in the work domain. Theoretical and empirical work conducted within self-determination theory (Deci \& Ryan, 2000) has consistently shown that satisfaction of basic needs for autonomy, competence and relatedness produce autonomous motivation in work settings (e.g. Baard, Deci, \& Ryan, 2004), and reliably predicts successful behaviour change in health contexts (Ng et al., 2012). Based on this body of evidence, basic psychological need satisfaction provides a useful construct for studying employee receptivity to employer-sponsored opportunities to enhance health and wellbeing.

Basic psychological need satisfaction and organisational trust are theoretically related, insofar as having basic needs met at work develops an employee's belief that their employer can and will safeguard their best interests (Stone, Deci, \& Ryan, 2009). These factors are included in this review because they direct attention towards an important cultural factor (i.e. trust) and relational factor (need satisfaction). At the cultural level, the content of an employee's trust beliefs is likely to emerge from direct experience, vicarious observations, and anecdotal reports about how the organisation conducts itself towards employees (Gillespie \& Dietz, 2009). More specifically, trust will form based on an assessment of how the organisation characteristically addresses a range of employee equity issues (e.g. gender, race, pay, career progression), provides safe working conditions (e.g. compliance with OH\&S legislation), provides adequate resources to employees (e.g. staff training) and demonstrates social responsibility (e.g. actively contributed to the wider community) (Dobrowolski, 2014). As such, organisational trust will indicate something about an employee's general receptivity towards any organisational initiative as it integrates micro level psychological processes and group dynamics with macro level organisational elements (Rousseau, Sitkin, Burt, \& Camerer, 1998).

This article has been underpinned by an assumption that WorkWell programs represent a form of support that is both needed and desired by employees. They may not be. When the motives for, and barriers to, participation (e.g. healthier lifestyle; time limitations) are momentarily set aside, it is pertinent to ask: "What form(s) of support do employees most want their employers to give?" As few studies have specifically considered this question, the final section of this article is dedicated to exploring it by using a subset of qualitative data extracted from a recently completed pilot study.

\section{Employee support preferences: Pilot data}


The following data were collected as part of a pilot study conducted with Company A (a manufacturer; 96 employees) and Company B (an industrial systems company; 3,000 employees nationwide). Part of the study included a 20-minute interview about participants' workplace experiences. The interviews were audio-taped and transcribed to permit an analysis of the employee stories. Across both organisations, a total of 60 employees were interviewed (Company A = 26; Company B = 34).

For the purpose of this article, only the qualitative data derived from the interviews is of interest. Whilst the study did not set out specifically to elicit responses about WorkWell programs per se, it was interested in what employees believed would be the most valuable form of support that could be provided by their employers. The question:

"What one thing could this company do to improve your experience on the job? Before answering this question, consider all the possibilities - everything from receiving higher pay, to a company gym, to more flexible work hours, or some other opportunity the company could give you. What would be the major thing that would make a difference to the way you feel at work?"

This portion of each interview was content analysed and themed to examine which forms of support were most prevalent in the minds of employees. As can be seen from Table 2 below, when participants were asked to name the single most important thing for improving their experience at work, the vast majority responded by citing some aspect of improved communication. Often this related to the frequency and flow of communication but equally often the emphasis seemed to be placed on the different aspects of communication quality (e.g. genuineness or authentic interest in others). For example, the following employee wanted:

...just better communications. And trying to understand, like, every person try to put themselves in the other department's shoes and try to understand where they're coming from, than them working against each other. [CB27]

Other themes that were well represented related to efficiency and adequate resourcing. Interestingly the theme of waste came up more strongly for Company A (a manufacturer), where many employees lamented the amount of wasted time and materials that occurred through inefficiencies of one sort or another. In many cases, communication also appeared to be at the core of these issues and would sometimes manifest itself as a frustration that both companies were failing to realize their potential, but more usually it would have a negative impact on employees' feelings of pride in their work and job satisfaction:

The reality is we just - we all - from what I see, most guys have a big sense of pride in their work. But they all get down in the dumps when they know there's just constant systemic failures, and then here it is...here's all the failures, try and make something of it. We all just want to see that management is actually managing stuff into a workable situation [CB01].

The availability of good quality tools, equipment and other resources was also critical for many, largely because they seemed to have a major bearing on whether people could complete tasks to a level that was satisfying. Whilst many of the other themes represented in Table 2 below were not unexpected (e.g. the importance of social connections), a couple of these themes are worthy of note. 
Table 2. Categorization of qualitative responses to question about employer support

\begin{tabular}{|c|c|c|}
\hline Theme & Count & Textual examples \\
\hline Communication flow & 26 & $\begin{array}{l}\text { For me, it's probably communication. And sometimes when you're going getting approval for something, you get a no - is perhaps, } \\
\text { giving a reason for that no, and giving that no in a timely manner, not just drawing it out. [B20] }\end{array}$ \\
\hline $\begin{array}{l}\text { Increased efficiency } \\
\text { (decreased waste) }\end{array}$ & 8 & $\begin{array}{l}\text { They also send that information back to management, to designers, whatever, and it doesn't get followed up on properly. Well, they } \\
\text { might talk about it but it doesn't actually get down on paper, change drawings, modified, updated, and then we just keep on doing } \\
\text { the same mistakes again and again. [A12] }\end{array}$ \\
\hline $\begin{array}{l}\text { Better resources \& } \\
\text { equipment }\end{array}$ & 7 & $\begin{array}{l}\text { Just be a bit more responsive to your needs, whether it be for materials or tools, or whatever... We've had situations where critical } \\
\text { equipment has failed, and then getting replacements for it take a long time, and I end up having to bring in other guys that have got } \\
\text { their equipment working down so that I can do that part of my job. [B10] }\end{array}$ \\
\hline Social connectivity & 7 & $\begin{array}{l}\text { I think we've got to do a better job of debriefing, and I think we've got to do a better job of creating campfires, so to speak, and } \\
\text { getting around to telling war stories...in a way that doesn't create defensiveness but that binds. [A27] }\end{array}$ \\
\hline $\begin{array}{l}\text { Collaboration between } \\
\text { management \& staff }\end{array}$ & 4 & $\begin{array}{l}\text { To have more say... and more authority to actually say what you think needs to be done, with ideas or whatever - but it seems to fall } \\
\text { on deaf ears more than it should. [B04] }\end{array}$ \\
\hline $\begin{array}{l}\text { Better pay/financial } \\
\text { support }\end{array}$ & 4 & $\begin{array}{l}\text { I would like the pay review to be looked upon because, yeah, my feeling is it won't even get something like a CPI increase. My pay } \\
\text { review looks to be pretty low, especially to the contribution you do to the business and the business is making good. [B25] }\end{array}$ \\
\hline $\begin{array}{l}\text { Appreciation and } \\
\text { recognition }\end{array}$ & 2 & $\begin{array}{l}\text { Everybody is putting their hand up but nobody is getting recognised. Another thing is there are people working under me getting } \\
\text { paid much more. And I'm looking after them - I'm running the shots and then you say, "Hang on, is that really worth it to me?" } \\
\text { [A02] }\end{array}$ \\
\hline $\begin{array}{l}\text { Career development } \\
\text { support }\end{array}$ & 2 & $\begin{array}{l}\text { The training is the biggest thing because as I say, my work life is almost finished so I'm not worried. It's the younger blokes that } \\
\text { don't have the experience because if you can get them trained up, the company would be a hell of a lot better company. [B12] }\end{array}$ \\
\hline Physical health support & 0 & No responses \\
\hline
\end{tabular}

Note: Textual examples are coded to reflect the participant's company and participant number (i.e. A01 represents participant 1 from Company A). 
First, the identification of better pay was only the most salient factor for $7 \%$ of the sample. Indeed, it was surprising how infrequently it was raised at all, especially given that a mention of pay was included in the interview instruction. On a couple of occasions when it was raised, the attitude seemed to be that pay was simply a given and something that you accepted when you signed up:
I don't look at it as being a financial [matter]. I think when you join an organisation, you know what the paying conditions are, you know what you're likely to get as paying conditions, you're likely to know what the lurks and perks are and if you join a company then, obviously, you've accepted that. [CB30]

For another employee who raised it, pay was not a critical motivator, as they had been attracted to Company B, its brand and the opportunities he believed the job would provide:

I took a pay cut to come to [company name] [CB09]

Second, very few references were made to the value or importance of receiving support for employees' physical health. However, one interviewee who did raise the possibility of a company gym also conveyed considerable ambivalence about the idea because he saw it as a solitary pursuit and he placed a greater weight on social connectivity:

Have a gym onsite, which won't happen...the gym membership might be okay, but that would then be individual [CA12]

What this exploratory data indicates is that the employees from both organisations seem to care more about the way employers communicate with them than anything else. Of course, communication pervades all aspects of life and, as such, a discrete separation of categories will always be problematic. Nonetheless, the data suggest that people desire a good relationship with the organisation they work for and are concerned with how much information is shared with them and the manner in which that is done.

\section{Discussion}

A striking feature of the data just presented was the relevance that many of the identified themes seem to have to the basic psychological needs of autonomy (the need to feel that one's actions are self-initiated and volitional), competence (the need to feel effective in the world) and relatedness (the need to experience warm, caring connection with others).

A supplementary analysis of Company A data (that included all employee suggestions, not just the most salient ones) provided some confirmation of this link to basic psychological needs. For example, numerous interviewees in that organisation expressed feelings of disempowerment due to a perceived disconnection between workers and management. As such, many expressed a desire for better individual and group-level communication (e.g. oneon-ones; staff meetings), which could allow employee ideas and perspectives to be acknowledged, considered and, where appropriate, acted upon. As the starting point for autonomy support is the acknowledgement of others' perspectives (Deci, Eghrari, Patrick \& Leone, 1994), managerial interactions that more frequently display genuine interest and receptivity towards employees' views represent an important gesture towards supporting personal autonomy (independently of whether those views directly influence decision making).

In addition, most interviewees seemed to want more support for competence. This included numerous requests for the upgrading of essential equipment, which seemed to be a major factor in production errors and materials wastage. Also important were structural changes that many believed would improve the quantity and quality of productive output, such as the 
creation of problem-solving forums, out-sourcing of some production jobs (that employees were less skilled in), and more timely correction of drawings to assist production.

Finally, many of the suggestions that focused on communication also displayed links to the need for relatedness. Several interviewees noted an increasing "us" and "them" mentality, with a division between mechanical designers and production staff being of greatest concern. One popular suggestion for improving inter-personal connections was to resume social activities, including restarting the social club or more simply taking opportunities to provide feedback (including acknowledging good performance) in more informal ways like BBQs, coffee catchups, and project completion celebrations.

\subsection{Supporting employee health and wellbeing at work}

To repeat an earlier point, when employees were asked to identify factors that would make the biggest difference to their experience at work, very few interviewees identified issues that are generally the principal focus of WorkWell programs (i.e. the promotion of physical health, the prevention of physical ill health and mental ill health). Rather, the vast majority of suggestions revolved around improvements in basic communication, job resourcing and social connectivity. Given that, it may be that companies making heavy investments in formal, structured employee wellbeing programs are pursuing relatively low-yield options. Whilst the North American ROI data reviewed earlier would suggest otherwise (i.e. that programs save much more money than they cost), some caution has been advised about these estimates as they are "often funded by employers implementing the programs, and these employers may desire a positive assessment to justify their investment decisions" (Goetzel \& Ozminkowski, 2008, p.309). In addition, there appears to be very little longitudinal data that can attest to the power of these programs for inducing sustained change.

To be clear, there is no suggestion here that organisations are misguided in seeking to support health and wellbeing amongst their workforces. Rather, the suggestion is that if organisations want to successfully implement WorkWell programs and maximize the benefits that might be derived from them, then a multiplicity of factors becomes important. The most fundamental of these factors is employee receptivity, or the degree to which employees are positively oriented towards a program, by virtue of what it represents for them and its perceived value for themselves or others. Put differently, employee receptivity is a motivational precondition for (at best) participating and taking part in a program, or (at worst) advocating for it and encouraging others.

Based on the review outlined earlier in this paper, there is reason to believe that some of the following factors may positively influence employee receptivity. However, it should be noted that these factors represent developing hypotheses, rather than evidence-based knowledge, and would need to be examined in future research:

- Alignment with employee needs. This could be done by collaborating with employees on the development of programs, in order to determine what dimensions of wellbeing are most salient for people and what services are most relevant. Indeed, employee consultation and involvement in program development would be a worthwhile variable to study when examining participation rates.

- Changing norms. Organisations may need to work on changing workplace norms, so that employers are not caught in a psychological wedge between what certain programs encourage people to do (e.g. take regular work breaks) and the unspoken rules of an organisation (e.g. work breaks are for the weak). Clear and 
observable modeling of positive behaviours (e.g. by a CEO) would be one way to achieve this, and future researchers may gain some insight into participation rates by examining the degree of sponsorship and advocacy provided by senior leaders.

- Address change readiness issues. As WorkWell programs often encourage changes in physical, nutritional, recreational, or social behaviour, it is important that people explore any ambivalence they might feel about such change. Supplementing such programs with health coaching represents a way of assisting people to address motivational issues critical to long-term change (Spence, Cavanagh, \& Grant, 2008), most obviously by assisting people to explore the pros and cons of adopting more positive health behaviours (Miller \& Rollnick, 2012).

- Motive transparency. Given that some level of cynicism and distrust is prevalent in most organisations, it would be advisable for sponsors of WorkWell programs to be honest about their motives. That is, if cost reduction and productivity enhancement are primary motivators then that should be stated, rather than attempting to hide these motivations beneath more benign 'happy-worker' style justifications.

- Genuine commitment to systemic change. Consistent with the argument advanced by Sloan (1987), receptivity is likely to be improved if the organisation makes it clear enhanced employee wellbeing is a goal being pursed via both individually focused programs (that employees need to drive) and programs that address broader systemic issues (that organisations need to drive). For example, announcing an innovation project based on greater collaboration between employees and managers (as a way to develop new projects) could reassure employees that the company was committed to a balanced responsibility for change and not simply executing a nefarious social control strategy (Holmqvist, 2009).

\subsection{Supporting basic psychological needs: A wellbeing program par excellence?}

Whilst employee receptivity may be malleable in the ways described above, it is possible to imagine circumstances where organisational trust or employee discontent might be so great that the introduction of WorkWell programs might be ill-advised (particularly if motives were not transparent or if the organisation showed no inclination to accompany it with genuine systemic level change). In such a circumstance, organisations might be better advised to refrain from making sizable investments in such programs, as this may result in unintended consequences like increased cynicism, heightened distrust and little or no ROI due to lower than usual participation rates. The data presented earlier suggest that organisations re-think their approach to improving employee wellbeing at work by concentrating on more basic human relations issues and, more specifically, focusing on better supporting the autonomy, competence and relatedness needs of employees.

Indeed, given the large volume of evidence that links basic need satisfaction to well-being across numerous life domains, including work (Van den Broeck, Vansteenkiste, De Witte, Soenens, \& Lens, 2010), it could be argued that a solid commitment to, and effective support of, basic psychological needs represents a foundational stone for establishing high levels of sustainable employee wellbeing. 


\section{Conclusion}

This paper set out to examine factors that surround participation in workplace health and wellbeing programs. After presenting a review of relevant literature and analyzing pilot data taken from an employee wellbeing research project, it is concluded that WorkWell programs do not seem to provide the type of support that employees most value from their employers. To modify a line from the 1989 movie, Field of Dreams, "if you build it, they may NOT come". Based on this exploratory investigation this appears to be because such programs do not provide employees with what they most need. It was also suggested that employee receptivity might be an important factor in making decisions about the implementation of such programs. More specifically, there may be times when organisations would be far better served by not investing in such schemes but, rather, focusing energy and effort on better managing the issues associated with creating positive human relations.

\section{Authors}

Gordon B. Spence

Sydney Business School

University of Wollongong

gspence@uow.edu.au

\section{Publishing Timeline}

Received 8 January 2015

Accepted 13 May 2015

Published 21 June 2015

\section{References}

Baard, P. P., Deci, E. L., \& Ryan, R. M. (2004). Intrinsic need satisfaction: A motivational basis of performance and well-being in two work settings. Journal of Applied Social Psychology, 34(10), 20452068. http://dx.doi.org/10.1111/j.1559-1816.2004.tb02690.x

Backhaus, K., \& Tikoo, S. (2004). Conceptualizing and researching employer branding. Career Development International, 9(5), 501-517. http://dx.doi.org/10.1108/13620430410550754

Baxter, S., Sanderson, K., Venn, A. J., Blizzard, C. L., \& Palmer, A. J. (2014). The relationship between return on investment and quality of study methodology in workplace health promotion programs. American Journal of Health Promotion, 28(6), 347-363. http://dx.doi.org/10.4278/ajhp.130731-LIT-395

Breslow, L., Fielding, J., Herrman, A. A., \& Wilbur, C. S. (1990). Worksite health promotion: Its evolution and the Johnson \& Johnson experience. Preventive Medicine, 19, 13-21. http://dx.doi.org/10.1016/0091$\underline{7435(90) 90002-2}$

Bright, D. R., Terrell, S. L., Rush, M. J., Kroustos, K. R., Stockert, A. L., Swanson, S. C., \& DiPietro, N. A. (2012). Employee attitudes toward participation in a work site-based health and wellness clinic. Journal of Pharmacy Practice, 25(5), 530-536. http://dx.doi.org/10.1177/0897190012442719

Brown, M., Metz, I., Cregan, C., \& Kulik, C. T. (2009). Irreconcilable differences: Strategic human resources management and employee well-being. Asia Pacific Journal of Human Resources, 47(3), 270294. http://dx.doi.org/10.1177/1038411109106859

Buck. (2014). Working well: A global survey of health promotion, workplace wellness, and prodcutivity strategies. Atlanta GA: Xerox and Buck Consultants.

Commonwealth of Australia (2015). National Partnership Agreement on Preventative Health. http://www.anpha.gov.au/internet/anpha/publishing.nsf/Content/npaph 
Crowther, I., Thwaites, M., \& Zhou, J. (2004). Measuring the benefits of corporate health and wellbeing initiatives. Monash University: Interdisciplinary Team Research, TravelSmart Victoria.

Deci, E. L., Eghrari, H., Patrick, B. C., \& Leone, D. (1994). Facilitating internalization: The selfdetermination theory perspective. Journal of Personality, 62, 119-142. http://dx.doi.org/10.1111/j.14676494.1994.tb00797.x

Deci, E. L., \& Ryan, R. M. (2000). The "what" and "why" of goal pursuits: Human needs and the selfdetermination of behavior. Psychological Inquiry, 11(4), 227-268. http://dx.doi.org/10.1207/S15327965PLI1104 01

Dietz, G., \& Den Hartog, D. N. (2006). Measuring trust inside organisations. Personnel Review, 35(5), 557588. http://dx.doi.org/10.1108/00483480610682299

Dobrowolski, Z. (2014). Building intra-organizational trust. Zarzadzanie Publiczne, 28(4), 341-354.

Gillespie, N., \& Dietz, G. (2009). Trust repair after an organization-level failure Academy of Management Review, 34(1), 127-145. http://dx.doi.org/10.5465/AMR.2009.35713319

Goetzel, R. Z., \& Ozminkowski, R. J. (2008). The health and cost benefits of work site health-promotion programs. Annual Review of Public Health, 29, 303-323.

http://dx.doi.org/10.1146/annurev.publhealth.29.020907.090930

Goss, D. (1997). Healthy discipline: Health proimotion at work. Electronic Journal of Radical Organisational Theory, 3(2).

Haunschild, A. (2003). Humanization through discipline: Foucault and the goodness of employee health programmes. Paper presented at the 2nd International CMS Conference, Manchester, UK.

Hobfoll, S. E. (2001). The influence of culture, community and the nested-self in the stress process: Advancing conservation of resources theory. Applied Psychology: an International Review, 50(3), 337421. http://dx.doi.org/10.1111/1464-0597.00062

Holmqvist, M. (2009). Corporate social responsibility as corporate social control: The case of work-site health promotion. Scandinavian Journal of Management, 25, 68-72. http://dx.doi.org/10.1016/j.scaman.2008.08.001

Joslin, B., Loewe, J. B., \& Peterson, N. A. (2006). Employee characteristics and participation in a worksite wellness programme. Health Education Journal, 65(4), 308-319. http://dx.doi.org/10.1177/0017896906069367

Lakerveld, J., Ijzelenberg, W., van Tulder, M. W., Hellemans, I. M., Rauwerda, J. A., van Rossum, A. C., \& Seidell, J. C. (2008). Motives for (not) participating in a lifestyle intervention trial. BMC Medical Research Methodology, 8, 17. http://dx.doi.org/10.1186/1471-2288-8-17

Linman, L., Bowling, M., Childress, J., Lindsay, G., Blakey, C., Pronk, S., . . Royall, P. (2008). Results of the 2004 national worksite health promotion survey. American Journal of Public Health, 98(8), 15031509. http://dx.doi.org/10.2105/AJPH.2006.100313

Linnan, L. A., Sorensen, G., Colditz, G., Klar, N., \& Emmons, K. M. (2001). Using theory to understand the multiple determinants of low participation in worksite health promotion programs. Health Education and Behavior, 28(5), 591-607. http://dx.doi.org/10.1177/109019810102800506

Mainsbridge, C., Cooley, D., Pedersen, S., Fraser, S., \& Cosgrove, M. (2011). The effect of a computer-based workplace health and wellbeing program on workplace health culture. Paper presented at the AARE Internationakl Research in Education Conference, Hobart, Australia.

McCarthy, G., Almeida, S., \& Ahrens, J. (2011). Understanding employee wellbeing practices in Australian organisations. International Journal of Health, Wellness and Society, 1(1), 181-197.

McGillivray, D. (2002). Health promotion in the workplace: A missed opportunity? Health Education, 102(2), 60-67. http://dx.doi.org/10.1108/09654280210418974

Miller, T. R., Zaloshnja, E., \& Spicer, R. S. (2007). Effectiveness and benefit-cost of peer-based workplace substance abuse prevention coupled with random testing. Accident Analysis and Prevention, 39(3), 565573. http://dx.doi.org/10.1016/j.aap.2006.10.001

Miller, W. R., \& Rollnick, S. (2012). Motivational Interviewing. New York: Guildfor Press.

Ng, J. Y. Y., Ntoumanis, N., Thøgersen-Ntoumani, C., Deci, E. L., Ryan, R. M., Duda, J. L., \& Williams, G. C. (2012). Self-determination theory applied to health contexts: A meta-analysis. Perspectives on Psychological Science, 7, 325-340. http://dx.doi.org/10.1177/1745691612447309 
Nixon, A. E., Mazzola, J. J., Bauer, J., Kruger, J. R., \& Spector, P. E. (2011). Can work make you sick? A meta-analysis of the relationships between job stressors and physical symptoms. Work and Stress, 25(1), 1-22. http://dx.doi.org/10.1080/02678373.2011.569175

Nohammer, E., Stummer, H., \& Schusterschitz, C. (2011). Improving employee well-being through worksite health promotion? The exployee's perspective. Journal of Public Health, 19, 121-129. http://dx.doi.org/10.1007/s10389-010-0364-4

Parks, K. M., \& Steelman, L. A. (2008). Organizational wellness programs: A meta-analysis. Journal of Occupational Health Psychology, 13(1), 58-68. http://dx.doi.org/10.1037/1076-8998.13.1.58

Pelletier, K. R. (2011). A review and analysis of the clinical and cost-effectiveness studies of comprehensive health promotion and disease management programs at the worksite: Update VIII 2008 to 2010. . Journal of Occupational and Environmental Medicine, 53(11), 1310-1331. http://dx.doi.org/10.1097//OM.0b013e3182337748

Peretz, M., \& McGraw, P. (2011). Trends in Australian human resource development practice, 1996-2009. Asia Pacific Journal of Human Resources, 49(1), 36-54. http://dx.doi.org/10.1177/1038411110391707

Person, A. L., Colby, S. E., Bulova, J. A., \& Eubanks, J. W. (2010). Barriers to participation in a worksite wellness program. Nutrition Research and Practice, 4(2), 149-154. http://dx.doi.org/10.4162/nrp.2010.4.2.149

Prochaska, J. M., Prochaska, J. O., \& Levesque, D. A. (2001). A transtheoretical approach to changing organizations. Administration and Policy in Mental Health and Mental Health Services Research, 28(4), 247-261. http://dx.doi.org/10.1023/A:1011155212811

PWC. (2010). Workplace Wellness in Australia. Aligning action with aims: Optimising the benefits of workplace wellness. Sydney: PWC.

Robroek, S. J. W., van Lenthe, F. J., van Empelen, P., \& Burdorf, A. (2009). Determinants of participation in worksite health promotion programmes: A systematic review. International Journal of Behavioural Nutrition and Physical Activity, 6, 26. http://dx.doi.org/10.1186/1479-5868-6-26

Rongen, A., Robroek, S. J. W., van Ginkel, W., Lindeboom, D., Pet, M., \& Burdorf, A. (2014). How needs and preferences of employees influence participation in health promotion programs: A six-month follow-up study. BMC Public Health, 14, 1277.

Rongen, A., Robroek, S. J. W., van Lenthe, F. J., \& Burdorf, A. (2013). Workplace health promotion: A meta-analysis of effectiveness. American Journal of Preventive Medicine, 44(4), 406-415. http://dx.doi.org/10.1016/j.amepre.2012.12.007

Rousseau, D. M., Sitkin, S. B., Burt, S. R., \& Camerer, C. (1998). Not so different after all: A crossdiscipline view of trust. Academy of Management Review, 23, 393-404. http://dx.doi.org/10.5465/AMR.1998.926617

Rula, E., \& Sacks, R. (2009). Incentives for health and wellness programs: Strategies, evidence and best practice. Outcome and Insights in Health Management, 1(3), 1-7.

Sloan, R. P. (1987). Workplace health promotion: A commentary on the evolution of a paradigm. Health Education Quarterly, 14(2), 181-194. http://dx.doi.org/10.1177/109019818701400205

Spence, G., Cavanagh, M., \& Grant, A. (2008). The integration of mindfulness training and health coaching: an exploratory study. Coaching: An International Journal of Theory, Research and Practice, 1(2), 145-163.

Stone, D. N., Deci, E. L., \& Ryan, R. M. (2009). Beyond talk: Creating autonomous motivation through self-determination theory. Journal of General Management, 34, 75-91.

Van den Broeck, A., Vansteenkiste, M., De Witte, H., Soenens, B., \& Lens, W. (2010). Capturing autonomy, competence, and relatedness at work: Construction and initial validation of the work-related basic need satisfaction scale. Journal of Occupational and Organisational Psychology, 83, 981-1002. http://dx.doi.org/10.1348/096317909X481382

Wainwright, D., \& Calnan, M. (2002). Work stress: The making of a modern epidemic. Buckingham, UK: Open University Press.

WHO. (1948). Preamble to the Constitution of the World Health Organization.

http://www.who.int/about/definition/en/print.html

WHO. (2007). Workers' health: Global plan of action. Geneva: WHO. 